УДК $930.2+27-732.3+27-175$

Irina Dergacheva

\title{
COMMEMORATIVE LITERARY MONUMENTS IN ANCIENT RUSSIA
}

The article discusses the memorial practices of ancient Russia on a concrete example of description of the history of the origin, development and authorship of Synodikon with literary introductions associated with the names of prominent church hierarchs St Joseph Volotsky and Nil of Sora, who played a key role in the development of Russian spiritual culture. With the help of source study (istochnikovedenie) the author explores the claims and counterclaims about the dating of redactions of the literary introduction and concludes that the earliest version of the text is linked with the literary and liturgical works and activity of Iosif Volotskii, abbot of Volokolamsk Monastery and a leading church figure in the debate over church landholding in the fifteenth century.

Keywords: source study (istochnikovedenie), synodic, eschatological representation, textual analysis, written records, the church hierarchy.

В статье рассматривается поминальная практика Древней Руси на конкретном примере описания истории возникновения, развития и атрибуции авторства Синодика с литературными предисловиями в контексте деятельности выдающихся церковных иерархов преподобных Иосифа Волоцкого и Нила Сорского, сыгравших ключевую роль в развитии русской духовной культуры. С помощью источниковедческого анализа автор приводит аргументы в пользу датирования редакций литературных предисловий и приходит к выводу, что самый ранний вариант текста связан с литературными и литургическими трудами Иосифа Волоцкого, игумена Волоколамского монастыря, проводившего полемику по поводу церковного землевладения в XV веке.

Кл ю че вы е сл ов а: источниковедение, синодик, эсхатологические представления, текстологический анализ, памятники письменности, церковная иерархия.

Notions of eschatology in ancient Russia and the culture of the Early Modern Period is disclosed in the Russian Synodicon, a book commemorating the names of the living and the dead, who were prayed for by the priests during church and funeral services, as well as in dirges.

The commemoration of ancestors, which emerged as a special ritual in the pre-civilization societies, finally took shape in Old Testament times. The Hebrews had a custom of breaking bread next to coffins at burial ceremonies 
so that they could share the bread with the poor. Upon the death of family members, generally all the relatives fasted and prayed for the deceased.

By the beginning of the third century, the custom of commemorating ancestors in the Christian Church had been established. This fact is evident from ancient liturgical services. Accordingly, the first sequences of liturgical prayers were established in apostolic times by the followers of Christ, Jacob and Mark, and subsequently revised by Vasily the Great in the fourth century. Indeed the liturgical texts of Vasily the Great, John Chrysostom and Gregorius Dialogus are still widely used in modern church services, having been edited, with the addition of new motets, during the 5th through 9th centuries.

The Synodicon inherited the Byzantine tradition of praying for the living and dead. It became one of the main sources for expressing the religious ontological doctrine of the Russian Orthodox Church, particularly in relation to the divine structure of the other world or the Final Judgment, which functions in accordance with a person's righteous or sinful past.

By the time the Synodicon became a significant book in the 15th century, a new, distinctive "folk" literary monument emerged, which has no analogies to Western perspectives. Generally Western views treat the afterlife of a person in terms of his past life and give "prescriptions" on how to obtain paradise, bliss and eternal life. The Synodicon and its copies, called by their compilers "blessed and useful", in contrast, represent a distinctive view of eschatological conceptions in ancient Russian scribes, especially about the mysteries of the other world.

There were actually three types of records for commemorating the dead, differing in content, usage and form, yet all were united under one common name: "The Synodicon". They were called The Ecumenical Synodicon [vselenskii sinodik], The Commemorative Synodicon [sinodik-pomiannik] and the Synodicon, which was a literary compilation [Дергачева, 2001].

The Ecumenical Synodicon is a part of the Synodicon, which was used during the feast of Orthodoxy, first practiced in Byzantine. Based upon the Seventh Ecumenical Council's decision to mark the final defeat of Iconoclasm, the text was read in churches during bishop's services on the first week of Great Lent.

The Commemorative Synodicon contained a list of names of the living and the dead, who were prayed for during church services. Such Synodicons were of several types, including fraternal, i.e. monastic, familial and military. The Commemorative Synodicon can also be divided into «eternal» and «daily», i. e. vsedennik, according to the time it took place, and was further subject to a contribution paid for the person commemorated. The opening part included prayers for bishops, Grand Dukes and princes with appanage, and is similar to the Russian part of the Ecumenical Synodicon. On the whole, the synodik-pomiannik is one of the most historically significant manuscripts [Дергачев, с. 210-225].

The third type of Synodicon, symbolically called the "Synodicon and literary compilation", consists of synodik-pomiannik and synodical forewords, which emphasize the importance of commemorating the deceased. 
This portion of the manuscript highlights Russian contributions to the Synodicon, especially as expressed through the views of particular authors.

The compiler and author of the first edition of the Synodicon with a three-tale foreword was the celebrated Russian educator, Joseph Volotsky, who drafted the earliest copy, the first edition of 1479 , which is available in manuscript [Малышев, с. 155-156]

On August $15^{\text {th }}, 1479$ the Cathedral of the Dormition, or Uspensky s ob or, in Joseph-Volotsky monastery was consecrated. Joseph wrote the Synodicon with a three-tale foreword, especially for this monastery. The first tale touches upon the healing power of such books on Judgment Day.

The second tale, demonstrating a connection to John Chrysostom, has a description of family commemoration, indicating that persons on Pomiannik's list will never be forgotten. The third and final tale instructs Father Superiors and priests to pray for the poor.

The confirmation and canonization of these texts with a three-tale foreword took place at the consecration of the Cathedral of Dormition in Moscow in 1479, which in effect made these texts compulsory for all the ecclesiastical provinces in Moscow.

Joseph Volotsky's Synodicon also contains extra forewords, which conclude by mentioning two princes: Boris Vasilievich Volotsky (died in 1494) and his son Ivan Borisovich (died in 1503) [Казакова, с. 354-357]. These extra tales were presumably added to the Synodicon soon after Ivan Borisovich's death, with the reason for the addition given by Joseph himself. Additionally, portions from the Speeches of Gregorius Dialogus "on the Lives of the Saints, on staretzs", are of interest because they show how Gregorius Dialogus divided sins into two classes: ones that cannot be forgiven, and ones that can be redeemed, even after death, in order to save the sinful soul.

The appearance of a Synodicon with forewords arguing forcefully for commemorating the dead was caused in part by wide-spread eschatological ideas of Joseph's contemporaries, who were anticipating the apocalypse in 1492, 7000 years presumably since the creation of the World. Nonetheless, another reason for the appearance is connected with the Heresy of the Judaizers or Zhidovstvuyushchiye, who seized Moscow and Novgorod at the end of the 15th century. When viewed from this event, the creation of the first Synodicon, which contains forewords drafted by the founder of Joseph Volotsky Monastery during the preparations for the last council on the point of the Heresy of the Judaizers (1504), reveals a singular response to the heresy of anti-trinitarians, who denied the healing power of funeral prayers and the concept of resurrection [Мильков; Громов, Мильков]. The heretics refused to admit the main points of the eschatological doctrine within the Synodicons: that is, personal judgment and the common Final Judgment of all the living and the dead.

At the time of the secularization of monastery lands by the government, approved by Non-possessors or nestyazhateli, the heretics were supported even by Tsar Ivan III. Additionally, since the apocalypse failed to occur in 1479, the Judaizers used this fact to bolster their doctrine. 
In such difficult conditions, Joseph, being a zealous accuser of the heresy of anti-trinitarians, united with the Non-possessors, who in turn were against Volotsky's policy of cooperating with the government in order to enlarge monastery lands. Joseph drafted consequently an entirely new and singular literary artifact within Russian culture: the Synodicon with its accompanying forewords.

Heresy was considered a mortal sin: "Alexei the archpriest died with his soul dead", as stated abruptly within a council decree in 1490 and quoted in Volotsky's The Enlighter [Казакова, Лурье, с. 468-475]. In this teeming social context, it becomes clear why the Synodicon opened with the division of forgivable and unforgivable sins.

The Homily of Macarius of Egypt on pagan priests states that Christian souls, who had a chance to recognize Christ, but nonetheless rejected him and even persisted in their heresy, were doomed to the worst suffering. The sins of the Judaizers, with regard to the words of Joseph, were unforgivable, which means that the Church did not have to concern itself with saving them. Non-possessors, who included Vassian Patrikeev as a leader, did not hold such a radical view and were in fact against the prosecution of heretics, and accused Joseph of carrying out such actions.

The next tale in the foreword, taken from the fourth book of Gregorius Dialogus, describes how the soul of the evil czar, Traian, was saved by a saint's prayer. The tales hinted at Joseph's struggle with the heresy and his decisive impact on the Grand Duke, who initially supported the Judizers.

The next copy of the Synodicon appeared in 1526, 11 years after the death of the archpriest, and was compiled by his apprentice, Serapion Polevoi [ГИМ, собр. Епархиальное № 411]. This edition was reconstructed from the copy of 1598's Volokolamsky Synodicon [РГАДА, ф. 1192. Собр. Иосифо-Волоколамского монастыря, оп. II. № 559; Синодик ИосифоВолокаламского монастыря].

Gregorius Dialogus's conception of forgivable and unforgivable sins yielded to synodic articles that vividly illustrated the possibility of God's mercy. Indeed even souls who committed deadly sins could be saved on the condition that they were not apostate, i. e. they realized the sinful nature of their deeds. An essential part of the first edition of the Synodicon is the prayer for all orthodox Christians.

The texts of the monastery of Pomianniks offer versions of a prayer by Patriarch Cyril of Jerusalem, who zealously struggled against the heresy of Ariy, which denied the divine nature of Christ.

The anathema of Ariy and his followers was reflected in the texts of the Ecumenical Synodicon. For instance, in the fifth part it states: «then we commemorate the deceased: patriarchs, prophets, martyrs for God to accept our request; later we commemorate the deceased saints and bishops and us all with a belief that this prayer will be of use for the souls, when a saint and formidable sacrifice is being made».

The name of Cyril in the title of the Prayer became a motive for the author, who described and catalogued Count A. S. Uvarov's manuscripts, to ascribe it to Cyril Turovsky [Рукописи графа Алексея Уварова, т. 2, 
c. 102-104, 157], despite the fact that the same author was aware of the list that contained Cyril of Jerusalem's name in its title [РНБ, ф. I.1].

Consequently, his hypothesis was supported by I .P. Eremin. M. S. Borovkova-Maikova pointed to the two copies from the 17th and 16th centuries, which contained "Nil Sorsky" in the title of the Prayer, having printed that text in a $17^{\text {th }}$-century copy from the collection of A. S. Uvarov [БоровковаМайкова, с. 12-15]

The text of the Prayer, in the $16^{\text {th }}$-century copy from the Sofia collection in The National Library of Russia (№ 1489), also contained a title linked with the name of "Nil". Commemorations in that Prayer differ in describing the various kinds of death, enumerated in the Apocalypses. References to "7000 years" are the author's individual insertions, confirming that the translation appeared in Russia on the eve of 7000 years, the date marking the creation of the world, before the 1492, modern system of chronology. The connection of both copies with "Nil" is apparently a reference to the name of the translator [Дергачева, 1990, с. 21-24]. An evident inspiration for the Nil-translator's work was his stay on the Athos.

It is also known that Joseph Volotsky widely used the texts, ascribed to Nil Sorsky, which obviously were translations in his own manuscripts, such as «the Message to an Iconographer» [Боровкова-Майкова, с. 15]. It is not accidental that the Prayer is a special addendum to the three-tale foreword, and it can be found in the copies of the first edition of Volotsky's Synodicon as well as the Pomiannik.

Cyril of Jerusalem's Prayer appeared throughout the manuscripts of Russian Synodicons. The Prayer of Common Commemoration, which contained a vast list of all kinds of passing, had been attached to Pomiannik until the 20th century. This text was continually expanded due to the added descriptions of kinds of passing, which in turn reveals how the text within the church service turned into a larger picture of common Russian life.

The main idea of Sorsky's translation is reflected in the three-tale synodic forewords. Nil Sorsky, being a famous church activist and polemicist took another position, in contrast to Joseph Volosky, on the fate of repentant heretics. He composed a manuscript that can nominally be called a Synodicon. Its only copy is traced to the 1850 s [Плигузов, с. 2, 3.]. A. I. Pliguzov defines the texts of the sammelband as well as "The Message of Joseph" and a reply to it (from the staretzs of St. Cyril's Monastery; p. 294-387) as "Nil Sorsky's Charter and a foreword to the Synodicon, titled with his name" [Там же, с. 2].

The foreword is Nil's translation of the Prayer for the deceased with a comprehensive enumeration of different kinds of death, which can be undoubtedly called a Synodicon foreword.

However the part of the Charter that deals with the concepts of commemoration and the Final Judgment makes up one whole text with the Prayer, and that text lays out the eschatological conception of "the saint hermit” [РНБ, Соф. 1489, л. 351 об.-387 об.]. Conditionally the compilation of those texts can be called, St. Nil's Synodicon. 
Unlike Joseph Volotsky, whose position on heresy is evident in the Synodicon forewords, St. Nil only gives examples that in turn demonstrate the necessity of commemoration. Evidence cannot be found of narrations with a teleological plot, loaned to Joseph from the saint father's collections, containing tales that condemn the heresy of denying resurrection and reward of an afterlife. In the form of didactic sermons, Saint Nil and Church Fathers - Philotheus Sinait, Anthony the Great, John Climacus, Isaac Sirin, Grigory Besedovnic, Roman the Melodist, John Chrysostom and apostle Matthew - demonstrate the importance of commemoration. Their sermons, widely used in later synodicons of the 17th century, focus on the theme of Vanitas, the mortality of the material world. An ascetic and a follower of Hesychasm, Saint Nil calls upon his congregation to think of death and the Final Judgment.

A teleological scheme, typical of forewords, loaned from the manuscripts of Saint Fathers, had become an essential part of all subsequent Synodicons: "A sin - a prayer, sacrifice; a liturgical service-absolution, instruction" or "a deadly sin - eternal suffering". Apostasy is the only unforgivable sin. The philosophical doctrine about retribution, encoded in the story of Macarius, had become essential for the Synodicons in later editions.

If the Synodicons of the Uspensky Cathedral on Volyn give only a general idea of Joseph's edition, then the Synodicon of Mikhailov Golden Domed Monastery in Kiev, 1553, represents a complete canonical form of the treetale foreword. The substitution of the name of Gregory of Nazianzus as a supporter of the divine afterlife with the name of Michael, the archangel and patron of the monastery and judge at the Final Judgment, gives an idea of the origins of the Synodicon. The text was revised by Simeon, the founder or a "builder" of the monastery.

The Stoglavy Sobor, 1551, set the conditions of the synodic foreword of Joseph's edition firmly into church practice. The 75th chapter of the Stoglav is entirely devoted to the idea of church's commemoration practice.

In the 16th century, the expectation for the apocalypse was finally replaced by constructive actions by the Moscow state. As a result of unifying political ideology, preached and encouraged both by the church and state, a theory of Moscow as the Third Rome materialized. No later than the year 1527, the first edition of "The Tale of the Princes of Vladimir" was composed, and in connection with the preparations for Ivan IV's coronation, a second edition appeared. The tale of Vladimir II Monomakh's obtaining of the czar's regalia was used as an introductory article to the sequence of Ivan the Fourth's (1547) coronation. In turn, Moscow's leading role in the Orthodox world stimulated cultural and educational activities: new saints were canonized and the Great Menaion Reader of Metropolitan Macarius was composed.

Great attention was paid to the practice of commemoration during Ivan IV's times [Дергачева, 1990, с. 34, 35]. It was subsequently set in law and led to the growth of the number of Synodicon manuscripts, creating a golden age for this literary monument in the 16th century. 
It is known that Synodicon commemorations were of great importance during Ivan IV's times, which is shown by the existence of «the synodicon of the disgraced (opalnye)» [Веселовский; Скрынников].

According to an analysis of the collected manuscripts, the following copies below were ascribed to Joseph's first edition (listed in chronological order):

- The Synodicon of the Monastery of Volokolamsk, 1479.

- The Synodicon of Pavlo-Obnorsky Monastery, till 1481.

- The Synodicon of the Monastery of Volokolamsk, a copy of 1526 from a Synodicon of 1479.

- $\quad$ The Synodicon of Novgorod Church of Boris and Gleb, 1552. 1560 [Шляпкин, с. 1].

- The Synodicon of Mikhail Golden-Domed Monastery, 1553-1560.

- The Synodicon of Moscow Great Uspensky Cathedral, $16^{\text {th }}$ century, the 60 s.

- The Synodicon of Moscow Great Uspensky Cathedral, $16^{\text {th }}$ century, the 60 s.

- The Synodicon of the Trinity Monastery of St. Sergius, 1575.

- The Synodicon of the Monastery of Kyrzhach, till 1585.

- The Synodicon of Moscow Epiphany Monastery with a list of names of those prosecuted by Ivan IV, 1599.

- The Synodicon of the Trinity Monastery on Tsna-river, 1620.

- The Synodicon of the Monastery of Kyrzhach, till 1631.

- The Synodicon of the Deacon Mikhail Patrikeevich Nasonov Church. 1633-1640.

- The Synodicon of Optina Monastery of Kozelsk, 1673-1690.

- The Synodicon of Kornil-Komelsky Monastery, $17^{\text {th }}$ century.

Боровкова-Майкова М. К литературной деятельности Нила Сорского // Памятники древней письменности и искусства. СПб. : ОЛДП, 1911. CLXXVII 19 с. [BorovkovaMaykova M. K literaturnoy deyatelnosti Nila Sorskogo // Pamyatniki drevney pismennosti i iskusstva. SPb. OLDP, 1911. CLXXVII 19 s.]

Веселовский С. Б. Исследования по истории опричнины. М. : Акад. наук СССР, 1963. 538 c. [Veselovskiy C. B. Issledovaniya po istorii oprichninyi. M. : Akad. Nauk SSSR, $1963.538 \mathrm{~s}$.

ГИМ. Собр. Уварова. № 1846 (754) (718). XVII в. Л. 791-793. Публикация; Собр. Епархиальное. № 411. [GIM. Sobr. Uvarova. № 1846 (754) (718). XVII v. L. 791—793. Publikacija; Sobr. Eparhial'noe. № 411].

Дергачев В. В. Родословие Дионисия Иконника // Памятники культуры. Новые открытия. Письменность. Искусство. Археология. Ежегодник. М. : Наука, 1989. C. 210-225. [Dergachev V. V. Rodoslovie Dionisija Ikonnika // Pamjatniki kul'tury. Novye otkrytija. Pis'mennost'. Iskusstvo. Arheologija. Ezhegodnik. M. : Nauka, 1989. S. 210-225].

Дергачева И. В. Становление повествовательных начал в древнерусской литератype. München : Verlag Otto Zagner, 1990. 210 c. [Dergacheva I. V. Stanovlenie povestvovatel'nyh nachal v drevnerusskoj literature. München : Verlag Otto Zagner, 1990. 210 s.]

Дергачева И. В. Синодик с литературными предисловиями: история возникновения и бытования на Руси // Древняя Русь. Вопр. медиевистики. 2001. № 2 (4). С. 89-96. [Dergacheva I. V. Sinodik s literaturnymi predislovijami: istorija vozniknovenija i bytovanija na Rusi // Drevnjaja Rus'. Vopr. medievistiki. 2001. № 2 (4). S. 89-96]. 
Казакова Н. А. Вассиан Патрикеев и его сочинения. М. ; Л. : Изд-во Акад. наук CCCP, 1960. 360 c. [Kazakova N. A. Vassian Patrikeev i ego sochinenija. M. ; L. : Izd-vo Akad. Nauk SSSR, 1960. 360 s.]

Казакова Н. А., Лурье Я. С. Антифеодальные еретические движения на Руси XIV начала XVI вв. М. ; Л. : Изд-во Акад. наук CCCP, 1955. 360 с. [Kazakova N. A., Lur'e Ja. S. Antifeodal'nye ereticheskie dvizhenija na Rusi XIV — nachala XVI vv. M. ; L. : Izd-vo Akad. Nauk SSSR, 1955. 360 s.]

Мальшев В. И. Древнерусские рукописи Пушкинского дома (обзор фондов). М. ; Л. : Ин-т рус. лит. Акад. наук, 1965. 235 с. [Malyshev V. I. Drevnerusskie rukopisi Pushkinskogo doma (obzor fondov). M. ; L. : In-t rus. lit. Akad. Nauk, 1965. 235 s.]

Мильков В. В. Антицерковные и еретические течения в древнерусской мысли // Громов М. Н., Мильков В. В. Идейные течения древнерусской мысли. СПб. : РХГИ, 2001. C. 260-342. [Mil'kov V. V. Anticerkovnye i ereticheskie techenija v drevnerusskoj mysli // Gromov M. N., Mil'kov V. V. Idejnye techenija drevnerusskoj mysli. SPb. : RHGI, 2001. S. 260-342].

Плигузов А. И. «Ответ Кирилловских старцев» // Древняя Русь. Вопр. медиевистики. 2001. № 3 (5). С. 1-17. [Pliguzov A. I. «Otvet Kirillovskih starcev» // Drevnjaja Rus'. Vopr. medievistiki. 2001. № 3 (5). S. 1-17].

РГАДА. Ф. 1192. Собр. Иосифо-Волоколамского монастыря. Оп. ИИ. № 559. [RGADA. F. 1192. Sobr. Iosifo-Volokolamskogo monastyrja. Op. II. № 559).]

РНБ. Ф. I.1.; Соф. 1489. 60-е гг. XVI в. Л. 290, 351 об.-387 об. [RNB. F. I.1. Sof. 1489. 60-e gg. XVI v. L. 290, 351 ob.-387 ob.)]

Рукописи графа Алексея Уварова. СПб. : Имп. Акад. наук, 1858. T. II. [Rukopisi grafa Alekseja Uvarova. SPb. : IMP Akad.nauk, 1858. T. II.]

Синодик Иосифо-Волокаламского монастыря (1479-1510-е годы) / подгот. текстов и исслед. Т. И. Шабловой. СПб. : Дмитрий Буланин, 2004. 224 с. (Святые и святыни Русской земли). [Synodik Iosifo-Volokolamskogo monastyrja (1479-1510) Shabalovoi. SPb. : Dmitryi Bulanin, 2004. 224 s.].

Скрынников Р. Г. Иван Грозный. М. : АСТ, 2001. 495 с. [Skrynnikov R. G. Ivan Groznyj. M. : AST, 2001. 495 s.]

Шляпкин И. А. Синодик 1552-1560 годов Новгородской Борисоглебской церкви. Белоостров, 1911 // Сборник Новгородского общества любителей древности. Вып. 5. Новгород : Губернская тип., 1911. [Shljapkin I. A. Sinodik 1552-1560 godov Novgorodskoj Borisoglebskoj cerkvi. Beloostrov, 1911 // Sbornik Novgorodskogo obshestva lubiteley drevnosti. Vip. 5. Novgorod : Gubernskaya tip., 1911].

The article was submitted on 10.01.2014

Ирина Дергачёва, проф.

Россия

Московский городской

психолого-педагогический

университет

krugh@yandex.ru
Irina Dergacheva, prof.

Russia

Moscow State University

of Psychology and Education

krugh@yandex.ru 